\title{
Frost flowers on sea ice as a source of sea salt and their influence on tropospheric halogen chemistry
}

\author{
L. Kaleschke, A. Richter, J. Burrows, O. Afe, G. Heygster, and J. Notholt \\ Institute of Environmental Physics, University of Bremen, Germany
}

\author{
A. M. Rankin and H. K. Roscoe \\ British Antarctic Survey, Natural Environment Research Council, Cambridge, UK
}

\section{J. Hollwedel and T. Wagner}

Institute of Environmental Physics, University of Heidelberg, Germany

\author{
H.-W. Jacobi \\ Alfred Wegener Institute for Polar and Marine Research, Bremerhaven, Germany
}

Received 2 June 2004; revised 21 July 2004; accepted 2 August 2004; published 25 August 2004.

[1] Frost flowers grow on newly-formed sea ice from a saturated water vapour layer. They provide a large effective surface area and a reservoir of sea salt ions in the liquid phase with triple the ion concentration of sea water. Recently, frost flowers have been recognised as the dominant source of sea salt aerosol in the Antarctic, and it has been speculated that they could be involved in processes causing severe tropospheric ozone depletion events during the polar sunrise. These events can be explained by heterogeneous autocatalytic reactions taking place on salt-laden ice surfaces which exponentially increase the reactive gas phase bromine ("bromine explosion"). We analyzed tropospheric bromine monoxide (BrO) and the sea ice coverage both measured from satellite sensors. Our model based interpretation shows that young ice regions potentially covered with frost flowers seem to be the source of bromine found in bromine explosion events. INDEX TERMS: 0322 Atmospheric Composition and Structure: Constituent sources and sinks; 1640 Global Change: Remote sensing; 3309 Meteorology and Atmospheric Dynamics: Climatology (1620); 3339 Meteorology and Atmospheric Dynamics: Ocean/atmosphere interactions $(0312,4504) ; 3360$ Meteorology and Atmospheric Dynamics: Remote sensing. Citation: Kaleschke, L., et al. (2004), Frost flowers on sea ice as a source of sea salt and their influence on tropospheric halogen chemistry, Geophys. Res. Lett., 31, L16114, doi:10.1029/ 2004GL020655.

\section{Introduction}

[2] The discovery of events of low ozone concentration in the atmospheric boundary layer at measurement stations located at high latitudes in the Northern Hemisphere has prompted much research into their origin. These events were found to be associated with enhanced amounts of inorganic bromine compounds [Barrie et al., 1988; McConnell et al., 1992; Fan and Jacob, 1992; Foster et al., 2001]. Similar episodes have been observed in the Southern Hemisphere at high latitudes [Wessel et al., 1998; Frieß et al., 2004]. The advent of the measurement

Copyright 2004 by the American Geophysical Union. 0094-8276/04/2004GL020655\$05.00 of tropospheric trace gases from space by the Global Ozone Monitoring Experiment, GOME, led to the discovery of enhanced amounts of $\mathrm{BrO}$ close to regions of sea ice in the Northern and the Southern Hemisphere [Richter et al., 1998; Wagner and Platt, 1998]. GOME measures the light scattered from the atmosphere and reflected by the ground between 240 and $790 \mathrm{~nm}$ wavelength with a horizontal ground resolution of about $320 \times 40 \mathrm{~km}^{2}$ [Burrows et al., 1999]. A retrieval algorithm, based on differential optical absorption spectroscopy (DOAS) and stratospheric $\mathrm{BrO}$ modeled by a three-dimensional radiative- dynamicalchemical model, yields the tropospheric fraction of the column density of $\mathrm{BrO}$ [Richter et al., 1998; Wagner and Platt, 1998; Chipperfield, 1999]. Bromine destroys ozone very efficiently in two interlinked catalytic cycles which produce $\mathrm{BrO}$ and $\mathrm{HOBr}$ in the gas-phase [Foster et al., 2001]. Gaseous $\mathrm{HOBr}$ reacts with $\mathrm{Br}$ ions in a slightly acidic sea salt solution and releases $\mathrm{Br}_{2}$ and $\mathrm{BrCl}$ into the gas phase [Fickert et al., 1999; Adams et al., 2002]. The photolabile $\mathrm{Br}_{2}$ molecule is subsequently photo-dissociated into atomic $\mathrm{Br}$ [Foster et al., 2001]. Therefore, every $\mathrm{Br}$ atom of the $\mathrm{HOBr}$ molecule entering the liquid phase has the potential to release two $\mathrm{Br}$ atoms to the gas phase. The above gives a simplified description of the heterogeneous autocatalytic reaction that causes an exponential increase of gaseous $\mathrm{Br}$ radicals, the so-called bromine explosion. The main source of bromine over the open oceans in the marine boundary layer outside the polar regions was identified to be sea salt aerosol generated by breaking waves on the ocean surface [Tang and McConnell, 1996; Vogt et al., 1996; Sander et al., 2003]. The processes and sources unique to the polar ocean surfaces still remained unidentified, though the highest $\mathrm{BrO}$ amounts have been observed over the sea ice during the polar sunrise [Ridley et al., 2003; Zeng et al., 2003; Frieß et $a l ., 2004]$. Recently, the potential role of frost flowers (Figure 1) in this processes has been raised [Rankin et al., 2002]. Frost flowers are ice crystals which grow on frozen leads (linear breaks in the sea ice cover) and polynyas (openings between drift ice and fast ice or the coast). Frost flowers exhibit enhanced salinities and bromide ion concentrations of about three times of that of bulk seawater [Perovich and Richter-Menge, 1994; Rankin et al., 2002]. 


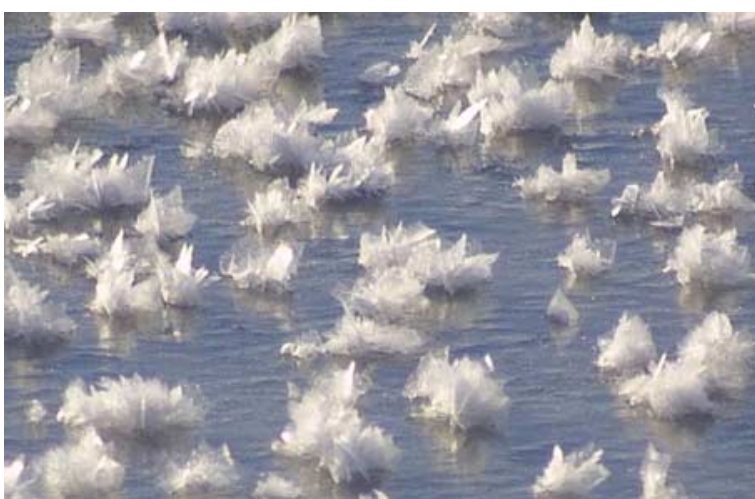

Figure 1. Frost flowers on sea ice covering a lead: Stellar dendrites of about 1 to $2 \mathrm{~cm}$ height on young sea ice (Courtesy of Stefan Kern, University of Hamburg). The photograph was taken at $75^{\circ} 58^{\prime} \mathrm{N} 25^{\circ} 34^{\prime} \mathrm{E}, 24$ March 2003. The air temperature was about $-18^{\circ} \mathrm{C}$.

Frost flowers only last for a few days until they are blown away by strong winds or covered by drifting snow [Perovich and Richter-Menge, 1994]. The aerosol produced by frost flowers was identified in Antarctic ice cores and at coastal stations due to its depleted sulfate to sodium ratio compared to the aerosol originating from the open ocean [Wagenbach et al., 1998; Rankin et al., 2002; Rankin and Wolff, 2003].

\section{Methods and Data Sets}

[3] It is assumed, that the open water area (which is given by one minus the sea ice concentration) will be covered soon with thin new ice on which frost flowers can grow. The sea ice concentration is determined from analyses of the thermal microwave emission measured by the Special Sensor Microwave Imager (SSM/I) aboard the Defense Meteorological Satellite Program (DMSP) platform using the ASI algorithm [Kaleschke et al., 2001; Maslanik and Stroeve, 2003]. Briefly this algorithm takes advantage of the higher polarisability of a specularly reflecting water surface compared to the more diffusely reflecting sea ice surface [Kaleschke et al., 2001; Kern et al., 2003].

[4] A one dimensional thermodynamic model has been developed to calculate the frost flower coverage (Figure 2). The model combines a frost flower growth parameterization obtained from laboratory experiments with the equations of sea ice heat balance which are described in more detail by Martin et al. [1996] and Maykut [1986]. We assume that the growth of frost flowers depends only on two basic prerequisites, the existence of new ice which is formed in leads or polynyas and of a strong negative temperature gradient above the ice surface. The two model input parameters, the surface air temperature $T_{a}$ and the open water $(\mathrm{OW})$ fraction, are taken from numerical weather prediction reanalysis data (NCEP/NCAR) and from satellite passive microwave measurements, respectively. The ice thickness $H=1.33 \Theta^{0.53}$ [cm] is calculated from the cumulative freezing days $\Theta=\int\left(T_{f}-T_{a}\right) d t$ with air temperature $T_{a}$ and the freezing point of sea water $T_{f}=-1.9^{\circ} \mathrm{C}$. The sea ice surface temperature $T_{0}=\frac{-15.96+H T_{a}}{8.4+H}$ is approximated for thin ice using an averaged heat transfer coefficient which describes both sensible and latent heat exchange [Maykut,
1986]. Assuming that the influence of a varying wind field and the insulating effect of frost flowers on the heat flux are negligible, then the frost flower growth rate $g=$ $0.000785 e^{0.478\left(T_{0}-T_{\mathrm{a}}\right)}$ is readily calculated using coefficients from laboratory experiments [Martin et al., 1996; Maykut, 1986]. The area coverage $F_{t}$ is calculated using the recursive expression $F_{t}=F_{t-\delta t}+g\left(1-F_{t-\delta t}\right) \delta t$ for a time step $\delta t$. Because the growth rate decreases rapidly as the ice thickness increases, the model yields a maximum percentage area $F_{\max }\left(T_{a}\right)$ covered by frost flowers for a given surface air temperature. This is defined as the relative potential frost flower (PFF) area. The total PFF area is obtained by weighting the total area with the new ice fraction. The predicted relative PFF areas for different integration times and air temperatures are presented in Figure 2. The height and hence the volume of the frost flowers cannot be calculated as the parameterization of the growth rate was derived from video images which measured the area coverage. As there is currently insufficient microphysical understanding about the initial nucleation and growth of frost flowers as well as about the decay processes, a minimum frost flower area for a given set of conditions cannot be estimated [Perovich and Richter-Menge, 1994; Martin et al., 1995, 1996]. The original aim of the above described method was to identify dates and regions worth to be analysed using costly very high resolution satellite images for the future development of a more direct frost flower retrieval algorithm [Kaleschke and Heygster, 2004].

\section{Comparison of Model Results and BrO Data}

[5] One typical example of the resulting PFF and the $\mathrm{BrO}$ data for the Antarctic is shown in Figure 3. The overall mechanism requires the release of bromine atom precursors, either directly on the frost flower surface or within its aerosol. We calculated forward air trajectories starting at regions with a high probability of frost flowers from the NCEP/NCAR Reanalysis surface wind field in order to account for the atmospheric transport of the aerosol or $\mathrm{BrO}$. Some regions with a high probability of frost flower occurrence for example at the Ronne-Filchner Ice Shelf in the Weddell Sea show no corresponding BrO plumes

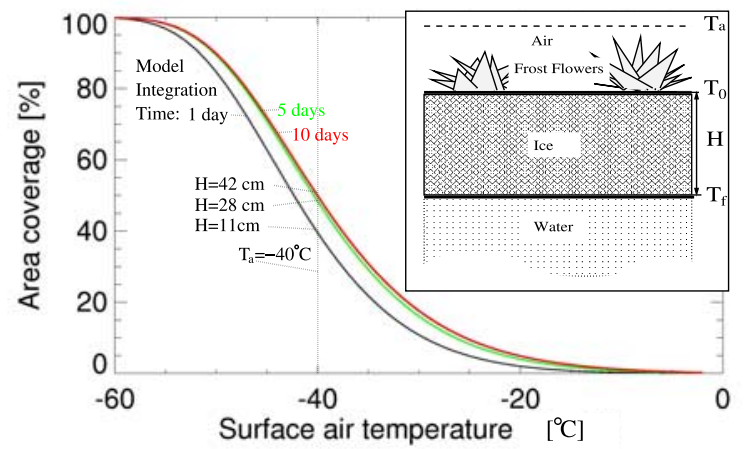

Figure 2. Frost flower model and frost flower coverage as a function of air temperature for different integration times. The three curves represent the integration times of one, five and ten days, respectively. The theoretical upper limit of frost flower coverage $F_{\max }\left(T_{a}\right)$ is approximately given by the upper curve. 


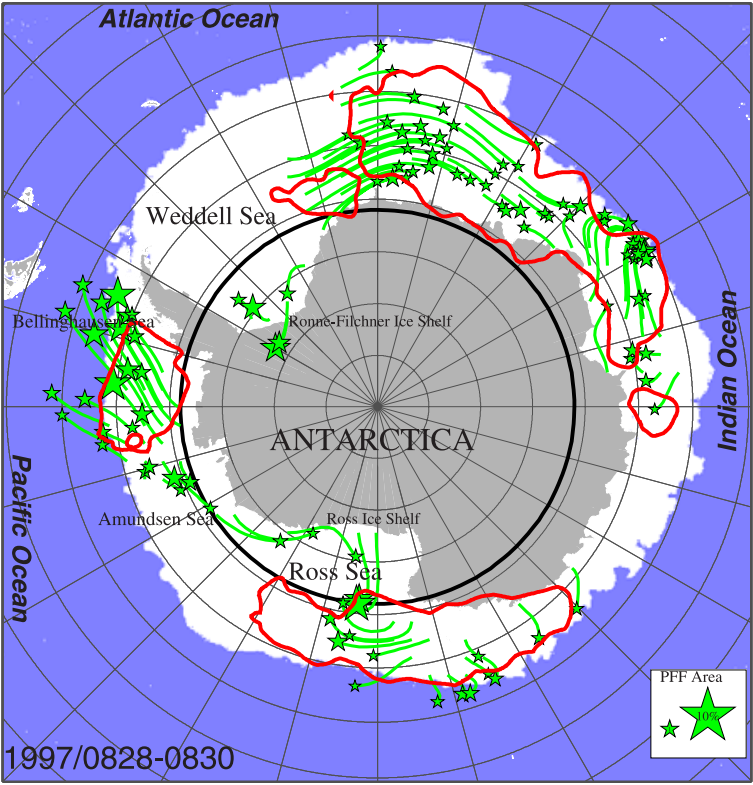

Figure 3. Comparison: Example total PFF coverage (green stars) and enhanced $\mathrm{BrO}$ amounts (red isolines) over the Antarctic ocean. The maximum values of two consecutive days are shown: from 28 to 29 and 29 to 30 August 1997 for PFF and $\mathrm{BrO}$, respectively. The green stars mark the endpoints of $24 \mathrm{~h}$ air trajectories starting at a frost flower area coverage of greater than $0.4 \%$, sampled every $187 \mathrm{~km}$. The PFF field was smoothed to $300 \mathrm{~km}$ spatial resolution to approximately match the GOME resolution. The total PFF coverage is proportional to the size of the stars. Two stars of $1 \%$ and $10 \%$ area coverage are shown in the lower right corner for comparison. The red isoline corresponds to enhanced $\mathrm{BrO}$ amounts of $3.6 \times$ $10^{13} \mathrm{molec} / \mathrm{cm}^{2}$ which is the mean (1.4) plus one standard deviation (2.2). The black circle indicates the almost dark latitudes (solar zenith angle $>80^{\circ}$ ). Sea ice covered regions are presented in white and the open ocean is coloured in blue.

because sunlight is needed for the photochemical reactions. The polynya at the Ross Ice Shelf that occurs frequently due to strong katabatic winds is shown to be a strong source of frost flower aerosol responsible for the enhanced $\mathrm{BrO}$ concentration farther north in the illuminated area. The trajectories are only a rough approximation as errors could occur in convective regions which are not well represented in the atmospheric boundary layer of the NCEP/NCAR model over sea ice [Kaleschke et al., 2001]. Nevertheless, more than ninety percent of the trajectories hit the enhanced $\mathrm{BrO}$ areas in Figure 3. One key area of frequently occurring ozone depletion events in the Arctic is shown in Figure 4. This typical example shows the huge (almost $500 \times 50 \mathrm{~km}^{2}$ ) recurring shore polynya in the northwest of the Hudson Bay which is potentially covered with frost flowers. This polynya frequently appears under offshore wind conditions.

[6] We investigated the entire 1996 to 2002 dataset and found commonly more than two third of the PFF trajectories hitting the enhanced $\mathrm{BrO}$ areas for the Arctic and Antarctic during polar sunrise. Almost all cases of enhanced $\mathrm{BrO}$ amounts were associated with a high probability of frost flowers on the previous days. Occasionally enhanced PFF values appear without enhanced $\mathrm{BrO}$ amounts. However, this does not reject the hypothesis of frost flowers causing $\mathrm{BrO}$ production as the $\mathrm{BrO}$ retrieval could be hampered by clouds [Richter et al., 1998; Wagner and Platt, 1998; Frie $\beta$ et al., 2004]. Furthermore, the PFF is a potential theoretical upper limit. Specific meteorological conditions could have prevented the actual growth of frost flowers. The influence of the wind is ambiguous: the dynamical opening of leads and polynyas is a wind driven effect and a prerequisite for thin ice production, but persisting strong winds could prevent the growth of frost flowers [Perovich and Richter-Menge, 1994]. Changing wind fields such as passing cyclones probably support the growth of frost flowers.

\section{Conclusion}

[7] It can be summarized that the sea salt and associated halogen flux from the ocean to the atmosphere is governed by different processes inside and outside the polar regions: Outside the polar regions, the sea salt is injected into the atmosphere by breaking waves on the ocean surface dominated by the wind [Sander et al., 2003]. Whereas the process inside the sea ice covered regions is mainly modulated by the air temperature [Zeng et al., 2003; Frie $\beta$ et al., 2004]. Previous work has been insufficient to localize the potential bromine sources [Richter et al., 1998; Wagner
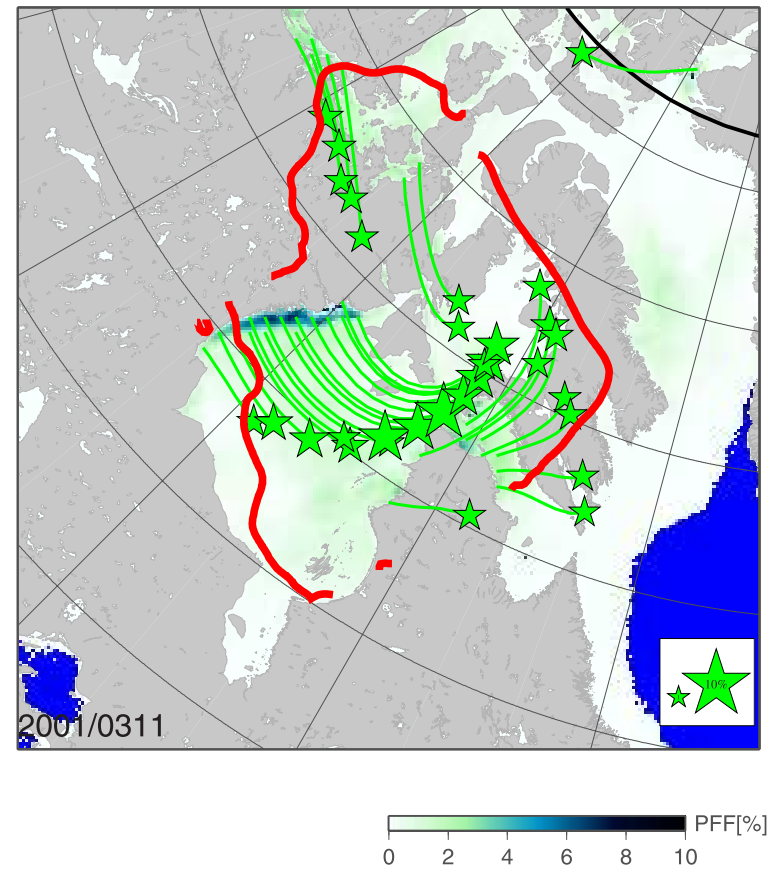

Figure 4. Example total PFF coverage (green stars) and enhanced $\mathrm{BrO}$ amounts (red isolines) over the Hudson Bay for 11 March 2001. Symbols and lines are similar to Figure 3, but the PFF coverage is displayed color coded. The $24 \mathrm{~h}$ air trajectories start at PFF greater than $1 \%$ sampled every $62.5 \mathrm{~km}$. The red isoline corresponds to enhanced $\mathrm{BrO}$ amounts of $8.8 \times 10^{13} \mathrm{molec} / \mathrm{cm}^{2}$ which is the mean (6.2) plus two standard deviations (1.3). The isoline is broken due to the data gaps of the GOME coverage. 
and Platt, 1998; Zeng et al., 2003; Ridley et al., 2003; Frieß et al., 2004]. We provided a method to localize the young ice regions potentially covered with frost flowers that seem to be a prerequisite for the bromine explosion. This provides a crucial step for a better understanding of the exchange processes between ocean, sea ice and atmosphere that are of great importance for the Earth's climate system [Shepson et al., 2003].

[8] Acknowledgments. L. K. and HW. J. gratefully acknowledge the German Research Foundation (DFG) for funding. L. K. thanks Gunnar Spreen, Stefan Kern, Roland von Glasow, Eric W. Wolff, Mark Drinkwater, Robert Ezraty, Wolfgang Dierking, Christof Lüpkes, Thomas Busche and Christian Haas for discussions.

\section{References}

Adams, J. W., N. S. Holmes, and J. N. Crowley (2002), Uptake and reaction of $\mathrm{HOBr}$ on frozen and dry $\mathrm{NaCl} / \mathrm{NaBr}$ surfaces between 253 and $233 \mathrm{~K}$, Atmos. Chem. Phys., 2, 79-91.

Barrie, L. A., J. W. Bottenheim, R. C. Schnell, P. J. Crutzen, and R. A Rasmussen (1988), Ozone destruction and photochemical reactions at polar sunrise in the lower Arctic atmosphere, Nature, 334, 138-141.

Burrows, J. P., et al. (1999), The global ozone monitoring experiment (GOME): Mission concept and first scientific results, J. Atmos. Sci., 56(2), $151-175$.

Chipperfield, M. P. (1999), Multiannual simulations with a threedimensional chemical transport model, J. Geophys. Res., 104(D1), $1781-1805$.

Fan, S. M., and D. J. Jacob (1992), Surface ozone depletion in Arctic spring sustained by bromine reactions on aerosols, Nature, 359, 524-552.

Fickert, S., J. W. Adams, and J. N. Crowley (1999), Activation of Br-2 and $\mathrm{BrCl}$ via uptake of $\mathrm{HOBr}$ onto aqueous salt solutions, J. Geophys. Res., 104(D19), 23,719-23,727

Foster, K. L., R. A. Plastridge, J. W. Bottenheim, P. B. Shepson, B. J. Finlayson-Pitts, and C. W. Spicer (2001), The role of $\mathrm{Br}-2$ and $\mathrm{BrCl}$ in surface ozone destruction at polar sunrise, Science, 291(5503), 471-474.

Frieß, U., J. Hollwedel, G. Konig-Langlo, T. Wagner, and U. Platt (2004), Dynamics and chemistry of tropospheric bromine explosion events in the Antarctic coastal region, J. Geophys. Res., 109(D6), D06305, doi:10.1029/2003JD004133.

Kaleschke, L., and G. Heygster (2004), Towards multisensor microwave remote sensing of frost flowers on sea ice, Ann. Glaciol., in press.

Kaleschke, L., C. Lüpkes, T. Vihma, J. Haarpaintner, A. Bochert, J. Hartmann, and G. Heygster (2001), SSM/I sea ice remote sensing for mesoscale ocean-atmosphere interaction analysis, Can. J. Remote Sens., 27(5), 526-537.

Kern, S., L. Kaleschke, and D. A. Clausi (2003), A comparison of two $85 \mathrm{GHz}$ SSM/I ice concentration algorithms with AVHRR and ERS-SAR, IEEE Trans. Geosci. Remote Sens., 41(10), 2294-2306.

Martin, S., R. Drucker, and M. Fort (1995), A laboratory study of frost flower growth on the surface of young sea ice, J. Geophys. Res., 100(C4), $7027-7036$

Martin, S., Y. Yu, and R. Drucker (1996), The temperature dependence of frost flower growth on laboratory sea ice and the effect of the flowers on infrared observations of the surface, J. Geophys. Res., 101(C5), 12,11112,125 .
Maslanik, J., and J. Stroeve (2003), DMSP SSM/I daily polar gridded brightness temperatures [CD-ROM], Natl. Snow and Ice Data Cent., Boulder, Colo.

Maykut, G. A. (1986), The surface heat and mass balance, in The Geophysics of Sea Ice, NATO ASI B146, edited by N. Untersteiner, pp. 395-463, Martinus Nijhoff, Zoetermeer, Netherlands.

McConnell, J. C., G. S. Henderson, L. A. Barrie, J. Bottenheim, H. Niki, C. H. Langford, and E. M. J. Templeton (1992), Photochemical bromine production implicated in Arctic boundary-layer ozone depletion, Nature, $355,150-152$.

Perovich, D., and J. A. Richter-Menge (1994), Surface characteristics of lead ice, J. Geophys. Res., 99(C8), 16,341-16,350.

Rankin, A., and E. W. Wolff (2003), A year-long record of size segregated aerosol composition at Halley, Antarctica, J. Geophys. Res., 108(D24), 4775, doi:10.1029/2003JD003993.

Rankin, A. M., E. W. Wolff, and S. Martin (2002), Frost flowers: Implications for tropospheric chemistry and ice core interpretation, J. Geophys. Res., 107(D23), 4683, doi:10.1029/2002JD002492.

Richter, A., F. Wittrock, M. Eisinger, and J. P. Burrows (1998), GOME observations of tropospheric $\mathrm{BrO}$ in Northern Hemispheric spring and summer 1997, Geophys. Res. Lett., 25(4), 2683-2686.

Ridley, B. A., et al. (2003), Ozone depletion events observed in the high latitude surface layer during the TOPSE aircraft program, J. Geophys. Res., 108(D4), 8356, doi:10.1029/2001JD001507.

Sander, R., et al. (2003), Inorganic bromine in the marine boundary layer: A critical review, Atmos. Chem. Phys., 3, 1301-1336.

Shepson, P., P. Matrai, L. Barrie, and J. Bottenheim (2003), Ocean-atmosphere-sea ice snowpack interactions in the Arctic and global change, Eos Trans. $A G U, 84(36), 349-355$.

Tang, T., and J. C. McConnell (1996), Autocatalytic release of bromine from Arctic snow pack during polar sunrise, Geophys. Res. Lett., 23(18), $2633-2636$.

Vogt, R., P. J. Crutzen, and R. Sander (1996), A mechanism for halogen release from sea-salt aerosol in the remote marine boundary layer, Nature, 383, 327-330.

Wagenbach, D., F. Ducroz, R. Mulvaney, L. Keck, A. Minikin, M. Legrand, J. S. Hall, and E. W. Wolff (1998), Sea-salt aerosol in coastal Antarctic regions, J. Geophys. Res., 103(D9), 10,961-10,974.

Wagner, T., and U. Platt (1998), Satellite mapping of enhanced BrO concentrations in the troposphere, Nature, 395, 486-490.

Wessel, S., S. Aoki, P. Winkler, R. Weller, A. Herber, H. Gernandt, and O. Schrems (1998), Tropospheric ozone depletion in polar regions: A comparison of observations in the Arctic and Antarctic, Tellus, Ser. B, $50(1), 34-50$.

Zeng, T., Y. H. Wang, K. Chance, E. V. Browell, B. A. Ridley, and E. L. Atlas (2003), Widespread persistent near-surface ozone depletion at northern high latitudes in spring, Geophys. Res. Lett., 30(24), 2298, doi:10.1029/2003GL018587.

O. Afe, J. Burrows, G. Heygster, L. Kaleschke, J. Notholt, and A. Richter, Institute of Environmental Physics, P.O. Box 330440, D-28334 Bremen, Germany. (lkalesch@iup.physik.uni-bremen.de)

J. Hollwedel and T. Wagner, Institute of Environmental Physics, University of Heidelberg, Germany.

H.-W. Jacobi, Alfred Wegener Institute for Polar and Marine Research, Bremerhaven, Germany.

A. M. Rankin and H. K. Roscoe, British Antarctic Survey, Natural Environment Research Council, Cambridge, UK. 